\title{
Sodium carbonate pretreatment: an approach towards desilication of paddy straw and enhancement in biogas production
}

\author{
Karamjeet Kaur · Urmila Gupta Phutela
}

Received: 22 April 2014/Revised: 4 January 2015/Accepted: 10 February 2015/Published online: 20 February 2015

(C) The Author(s) 2015. This article is published with open access at Springerlink.com

\begin{abstract}
Lignocellulosic biomass is a useful but an inconvenient form of energy, and paddy straw (PS) is one of the most abundant lignocellulosic wastes on the earth. Lignocellulosics generally have a high content of cellulose having combustion energy of $15 \mathrm{~kJ} / \mathrm{g}$ which, when converted to methane, have a combustible energy of $50 \mathrm{~kJ} / \mathrm{g}$. But lignin and silica are the main deterrents for the microbial action on the cellulose/hemi-cellulose component of PS. In order to break the protective shield made by lignin and silica and to enhance the PS digestibility, the PS was pretreated with different concentrations $(2,4,6,8$ and $10 \%)$ of sodium carbonate by soaking the PS in sodium carbonate solution for the periods of 24 and $48 \mathrm{~h}$ and simultaneously irradiating the other set with microwaves (power $720 \mathrm{~W}$, temperature $180{ }^{\circ} \mathrm{C}$ ) for 30 and $60 \mathrm{~min}$. The change in chemical composition of PS was the factor determining the enhancement in PS digestibility. Sodium carbonate $(4 \%)+$ microwave $(60 \mathrm{~min})$ pretreatment was found to be the best amongst the other pretreatments with $84.9 \%$ desilication of PS and 44.3 and $54.4 \%$ increase in cellulose and biogas production, respectively.
\end{abstract}

Keywords Paddy straw $\cdot$ Pretreatment $\cdot$ Sodium carbonate $\cdot$ Microwave $\cdot$ Biogas production

\section{Introduction}

Biomass can be classified into three main categories: sugar-, starch- and cellulose-containing plants. Sugar- and

K. Kaur $(\varangle)$ - U. G. Phutela

School of Energy Studies for Agriculture, College of

Agricultural Engineering and Technology, Punjab Agricultural

University, Ludhiana 141004, Punjab, India

e-mail: karamjeet7@gmail.com starch-containing plants are generally used as food sources, while cellulose-containing plants and their waste products (e.g., grasses, wood, bagasse and straws) are the most abundant form of biomass (Holtzapple and Davison 1999). Lignocellulosic biomass is defined as contemporary plant matter (Frank and Smith 1988) which is continually being replenished by the photosynthetic reduction of carbon dioxide $\left(\mathrm{CO}_{2}\right)$ by sun energy (Zhang and Lynd 2004; Ragauskas et al. 2006; Saratale et al. 2008). Lignocellulosic biomass/agricultural residue is a useful but an inconvenient form of energy. Lignocellulosic biomass generally has a high content of cellulose having combustion energy of $15 \mathrm{~kJ} / \mathrm{g}$ which, when converted to methane, has a combustible energy of $50 \mathrm{~kJ} / \mathrm{g}$ (Khan et al. 1983). It can be burnt, but the efficiency of combustion is reduced by the moisture content, if it is not dried. Alternatively, lignocellulosic biomass can be converted to methane via anaerobic digestion (Kashyap et al. 2003).

Anaerobic digestion is bioconversion of organic wastes such as sewage, animal manure, food wastes and municipal solid wastes to biogas. During the process, the biomass is transformed into biogas which is a clean fuel for energy generation. Biogas is composed of $\mathrm{CH}_{4}(55-65 \%), \mathrm{CO}_{2}$ (30-45\%), $\mathrm{H}_{2}(1-5 \%), \mathrm{N}_{2}(0.5-2.0 \%), \mathrm{H}_{2} \mathrm{~S}(0.1-0.5 \%)$, $\mathrm{CO}(0-0.3 \%)$ and traces of water vapours (Pauss et al. 1987). Biogas generation involves consortium of microorganisms which is a group of hydrolytic, acidogenic and methanogenic bacteria. Paddy straw (PS), being a lignocellulose, consists of cellulose (35-40\%), hemi-cellulose $(20 \%)$, lignin $(12 \%)$ and silica (8\%). Although PS has high cellulose content, the lignin complex and silica incrustation shield the microbial action on it.

Therefore, the PS needs to be pretreated in order to enable cellulose/hemi-cellulose to be more accessible to the microbial/enzymatic attack for biogas generation. 
Accordingly, many physical (mechanical and nonmechanical), chemical (alkaline hydrolysis, acid hydrolysis, oxidative delignification and solvent extraction), physico-chemical (AFEX, $\mathrm{CO}_{2}$ and steam explosion) and biological pretreatments (lignocellulolytic micro-organisms and enzymes) have been proposed in the recent years (Holtzapple and Davison 1999; Saratale et al. 2008; Hendriks and Zeeman 2009). These pretreatment technologies either change or remove structural and compositional constraints to improve hydrolysis rate (Moseir et al. 2005). Ma et al. (2009) reported an increase of $30.6 \%$ cellulose and $43.3 \%$ hemi-cellulose content of PS by microwave pretreatment $(680 \mathrm{~W}, 24 \mathrm{~min})$. Microwave/alkali-pretreated rice straw could achieve higher ethanol concentration and yield than the alkali-alone-pretreated rice straw (Zhu et al. 2005). Some studies have shown that microwave irradiation could change the ultra-structure of cellulose (Xiong et al. 2000), degrade lignin and hemi-cellulose and increase enzyme susceptibility (Azuma et al. 1984; Ooshima et al. 1984; Kitchaiya et al. 2003). $\mathrm{NH}_{3}$ and urea simply crack the silicified cuticular layer of PS but did not dissolve silica (Van Soest 2006). Wang et al. (2007) reported that $\mathrm{NaOH}$ and $\mathrm{NH}_{4} \mathrm{HCO}_{3}$, respectively, dissolves and cracks off the cuticle wax silica layer of rice stem epidermis resulting in the degradation of epidermis by rumen micro-organisms. Oxygen-sodium sulphite pulping method was reported to be better than conventional alkaline pulping with $95 \%$ delignification and high retention of both cellulose and hemi-cellulose (Park et al. 2000). Lignin and cellulose degradabilities in cedar wood cultured with Ceriporiopsis subvermispora were found to be more in comparison to that cultured with Lentinula edodes (Okano et al. 2005). Sodium hydroxide-pretreated corn stalks were reported to produce $78.3 \%$ more biogas than untreated stalks and $13.2 \%$ more than the stalks treated with Pleurotus florida (Yang et al. 2003). Although there have been many pretreatment methods, few can be used at an industrial scale based on economics and environmental considerations (Sun and Cheng 2002). Variation in biogas yield from grasses is very much affected by the plant part used, harvesting frequency, plant age, clonal variations, nutrient addition, particle size reduction and various pretreatments (Gunaseelan 1997).

So keeping in view all these aspects and the importance of PS for energy and power generation along with combating the environmental pollution, the pretreatment of PS with sodium carbonate and microwave was investigated and its effect on PS composition and biogas production was studied.

\section{Methods}

Procurement of the materials

PS was procured from the research field of Punjab Agricultural University, Ludhiana, after the harvesting of the crop. The PS was chopped to $3-5 \mathrm{~cm}$ and was stored in polythene bags at room temperature. Digested biogas slurry was procured from a working biogas plant in Biogas Field Laboratory of School of Energy Studies for Agriculture, PAU, Ludhiana.

\section{Chemical pretreatment of PS}

PS was pretreated with sodium carbonate $\left(\mathrm{Na}_{2} \mathrm{CO}_{3}\right)$ and its effect on PS degradation was studied. The PS was soaked in $\mathrm{Na}_{2} \mathrm{CO}_{3}$ solution for different durations as one set, and $\mathrm{Na}_{2} \mathrm{CO}_{3}$ solution-dipped PS was irradiated with microwave irradiations as another set.

\section{$\mathrm{Na}_{2} \mathrm{CO}_{3}$-soaking pretreatment}

Twenty gram of chopped, washed and dried PS was soaked in $200 \mathrm{ml} \mathrm{Na}{ }_{2} \mathrm{CO}_{3}$ solution $(2,4,6,8$ and $10 \%)$ for different durations viz., 24 and $48 \mathrm{~h}$. After the desired period of soaking, the chemical solution was decanted off and PS was washed with tap water until the washings were clean, colourless and neutral to the $\mathrm{pH}$ paper. The PS was then dried overnight in the oven at $100{ }^{\circ} \mathrm{C}$. After drying, PS was ground. Ground, chemically pretreated PS was stored in polythene bags and was used for proximate [total solids (TSs), volatile solids (VSs), total organic carbon (TOC), and ash] and chemical (cellulose, hemi-cellulose, lignin and silica) analysis. Total sugars of the pretreated straw were also determined. A control (untreated PS) was analysed simultaneously in order to determine the extent of degradation of various components of PS.

\section{$\mathrm{Na}_{2} \mathrm{CO}_{3}$-microwave pretreatment}

Twenty gram of PS was suspended in $200 \mathrm{ml} \mathrm{Na} \mathrm{NO}_{3}$ solution of different concentrations as mentioned above in $500-\mathrm{ml}$ beakers (in two sets). Two beakers of same concentration were positioned at the centre of the rotating circular glass plate in the microwave oven (MC-2681DS, LG Electronics India Pvt. Ltd.) at a time and were irradiated with microwave power of $720 \mathrm{~W}$ at the temperature of $180{ }^{\circ} \mathrm{C}$ for 30 and $60 \mathrm{~min}$, respectively, for the two sets. Pretreated PS was washed with tap water until the 
washings were clean, colourless and neutral to the $\mathrm{pH}$ paper. PS was dried overnight in an oven at $100{ }^{\circ} \mathrm{C}$. Pretreated PS was then ground. To avoid drying and charring of PS in 60 min of pretreatment, the amount of chemical solution added was doubled. A control was also run simultaneously.

Scanning electron microscopy of the pretreated PS

The pretreated PS was analysed for structural changes through scanning electron microscopy at Electron Microscopy and Nanoscience Laboratory, PAU, Ludhiana, Punjab. The pretreated PS was processed for viewing under SEM which involved dehydrating the sample with the increasing alcohol series followed by mounting of the sample on the stub using carbon-tape, then sputter coating the sample with gold $(\mathrm{Au})$ nanoparticles and finally viewing under the scanning electron microscope. The samples were viewed at the following working conditions:

- Accelerating voltage $15,000 \mathrm{~V}$,

- Emission current 123,000 nA,

- Vacuum $15 \mathrm{kV}$,

- Magnification $\times 1.50 \mathrm{~K}$,

- Working distance $12.7 \mathrm{~mm}$.

\section{Biogas production from pretreated PS}

Biogas production experiments were carried out in glass biogas digesters of 21 capacity following monophasic method, and biogas produced was measured by water displacement method. Two different concentrations, i.e., 4 and $10 \%$, were selected on the basis of significant (for the former) and maximum (for the latter) increase in cellulose content and decrease in silica content. The selected pretreatments were taken up for biogas production. One hundred gram of the pretreated PS was mixed with $100 \mathrm{ml}$ of the digested biogas slurry and $100 \mathrm{ml}$ of tap water. The mixture was fed to biogas digesters which were incubated at $37 \pm 2{ }^{\circ} \mathrm{C}$. Biogas produced was measured daily for a period of 45 days. A control was also run where untreated PS was taken instead of pretreated PS.

\section{Analytical procedures}

The proximate (TS, VS, TOC and ash) and chemical (cellulose, hemi-cellulose, lignin and silica content) analysis of PS was done according to the procedures given in the Standard AOAC Methods (Thiex 2000). Total sugars were estimated by phenol-sulphuric acid method using glucose as a standard (Dubois et al. 1956).
Statistical analysis

All treatments were completed in triplicate. Critical difference at $5 \%$ level was performed for proximate and chemical analysis of PS using programme Factorial Experiments in CRD of CPCS1 software (developed by Department of Statistics, PAU, Ludhiana, Punjab).

\section{Results and discussion}

Effect of $\mathrm{Na}_{2} \mathrm{CO}_{3}$-soaking pretreatment on PS degradation

A significant weight loss was observed, and the pretreated sample became fragile and lighter in colour with the increasing $\mathrm{Na}_{2} \mathrm{CO}_{3}$ concentration. Results from Table 1 indicate a non-significant increase in TS and a significant increase in VS and TOC contents of PS with respect to increasing $\mathrm{Na}_{2} \mathrm{CO}_{3}$ concentration. TS, VS and TOC increased to $96.9,92.1$ and $51.2 \%$ and $97.0,92.6$ and $51.4 \%$, respectively, for $10 \% \mathrm{Na}_{2} \mathrm{CO}_{3}-24 \mathrm{~h}$ soaking and $10 \% \mathrm{Na}_{2} \mathrm{CO}_{3}-48 \mathrm{~h}$ soaking. Ash content decreased to 7.9 and $7.4 \%$ at $10 \% \mathrm{Na}_{2} \mathrm{CO}_{3}$ for 24 and $48 \mathrm{~h}$, respectively.

Total sugars decreased significantly with the increasing $\mathrm{Na}_{2} \mathrm{CO}_{3}$ concentration and soaking period reaching almost half the value than that in the control. Total sugars were found to decrease from $54.9 \mathrm{mg} / \mathrm{g}$ PS in control to 29.4 and $27.4 \mathrm{mg} / \mathrm{g}$ PS in $10 \% \mathrm{Na}_{2} \mathrm{CO}_{3}-24 \mathrm{~h}$ soaking and $10 \%$ $\mathrm{Na}_{2} \mathrm{CO}_{3}-48 \mathrm{~h}$ soaking, respectively. Cellulose increased significantly with the increasing $\mathrm{Na}_{2} \mathrm{CO}_{3}$ concentration and soaking period reaching a maximum of 49.9 and $50.2 \%$ at $10 \% \mathrm{Na}_{2} \mathrm{CO}_{3}$ for 24 and $48 \mathrm{~h}$ of soaking period indicating an increase of 14.4 and $15.1 \%$ in comparison to that of the control $(43.6 \%)$. Hemi-cellulose and lignin increased significantly with the increasing $\mathrm{Na}_{2} \mathrm{CO}_{3}$ concentration, but this increase was non-significant with respect to the increasing soaking period. Hemi-cellulose increased to a maximum of 26.1 and $26 \%$, while lignin reached a maximum of 6.5 and 6.9 at $10 \% \mathrm{Na}_{2} \mathrm{CO}_{3}-24 \mathrm{~h}$ soaking and $10 \% \mathrm{Na}_{2} \mathrm{CO}_{3}-48 \mathrm{~h}$ soaking, respectively. Silica decreased to such an extent that it remained only about half as compared to the control. This decrease in silica was significant with respect to the increase in $\mathrm{Na}_{2} \mathrm{CO}_{3}$ concentration and non-significant with the increasing period of soaking. Silica decreased to 2.8 and $2.5 \%$ from $5.3 \%$ in control accounting to a decrease of 47.2 and $52.8 \%$ as compared to the control.

Decrease in total sugars might be attributed to the fact that either there was no conversion of cellulose/hemi-cellulose to fermentable sugars or if these components had undergone 


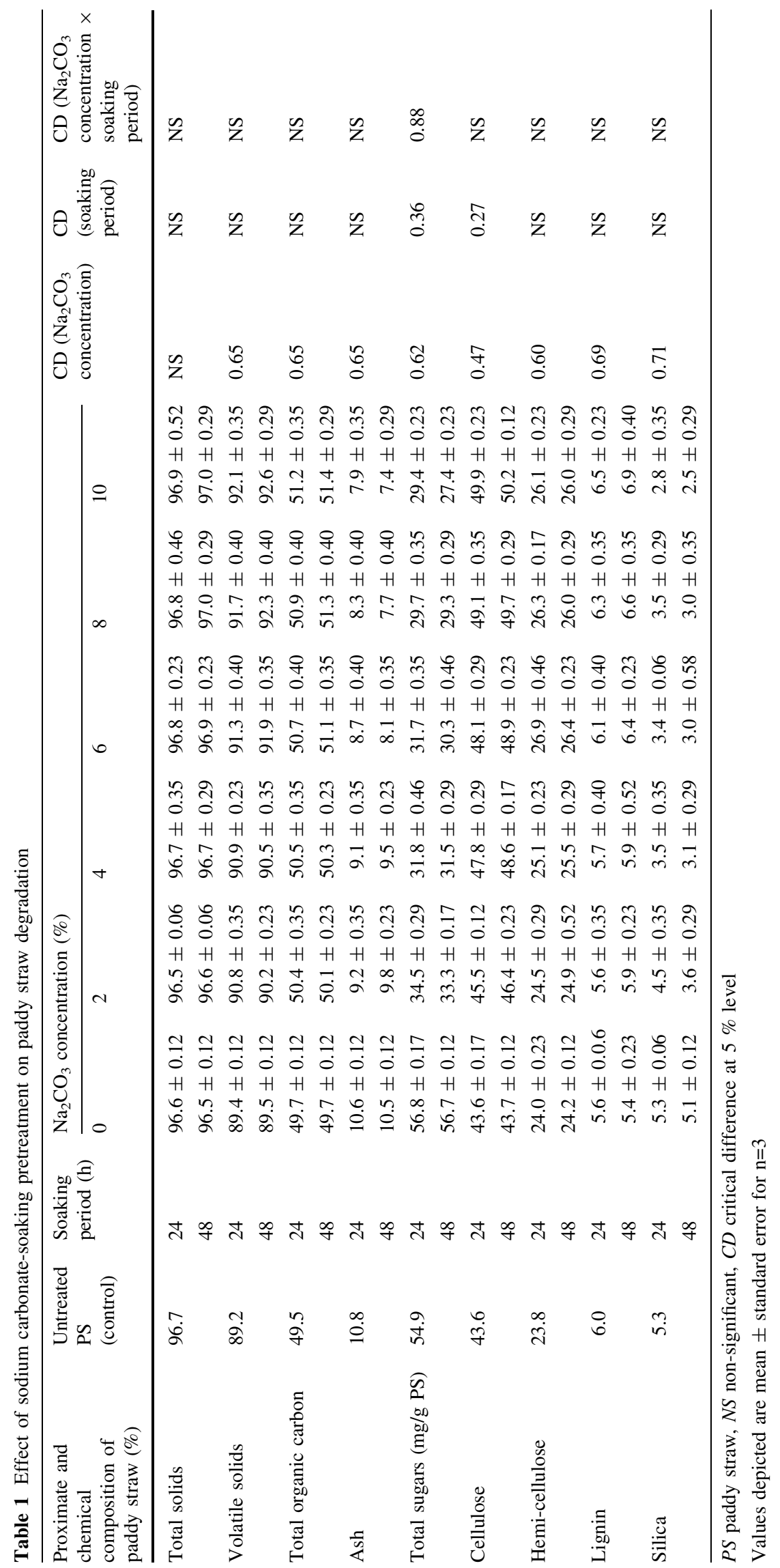


hydrolysis, these might have got converted to acids, furfural, hydroxyl methyl furfural or other degradation products. Limited increase of cellulose was found to be the result of increase in lignin content which did not allow the profound exposure of cellulose. Increase in hemi-cellulose could be due to the breakage of the hemicellulose-lignin complex resulting in freely available hemi-cellulose. Enhancement in lignin content might be the result of re-precipitation or condensation of the soluble lignin components over the PS. Decrease in silica was attributed to the fact that silica got removed by the action of $\mathrm{Na}_{2} \mathrm{CO}_{3}$.

Effect of $\mathrm{Na}_{2} \mathrm{CO}_{3}$-microwave pretreatment on PS degradation

The weight loss, fragility and lightness in colour of pretreated PS get increased with the microwave supplementation in contrast to soaking. Results from Table 2 indicate a non-significant increase in TS with the increasing $\mathrm{Na}_{2} \mathrm{CO}_{3}$ concentration, but TS was found to decrease with the increase in soaking period. VS and TOC increased significantly to a maximum of 95.1 and $95.9 \%$, and 52.8 and $53.3 \%$, respectively, with the increasing $\mathrm{Na}_{2} \mathrm{CO}_{3}$ concentration and soaking period. Ash content decreased significantly to half of that of the control. A decrease of 54.6 and $62 \%$ in ash was found at $10 \% \mathrm{Na}_{2} \mathrm{CO}_{3}-30 \mathrm{~min}$ microwave pretreatment $\left(4.9 \%\right.$ ) and $10 \% \mathrm{Na}_{2} \mathrm{CO}_{3}-60$ min microwave pretreatment $(4.1 \%)$, respectively. Decrease in total sugars was also significant with respect to both the parameters. Total sugars decreased to 27.5 and $25.4 \mathrm{mg} / \mathrm{g}$ PS at $10 \%$ $\mathrm{Na}_{2} \mathrm{CO}_{3}$ for 30 and 60 min of microwave duration, respectively, indicating a decrease of 49.9 and $53.7 \%$ than that of the control (54.9 $\mathrm{mg}$ total sugars/g PS).

Cellulose increased significantly to 62.7 and $66.5 \%$ at $10 \% \mathrm{Na}_{2} \mathrm{CO}_{3}$ with the increasing microwave durations showing an increase of 43.8 and $52.5 \%$ than that of the control (43.6\%). Hemi-cellulose decreased significantly to 20.4 and $20.1 \%$ at $10 \% \mathrm{Na}_{2} \mathrm{CO}_{3}-30 \mathrm{~min}$ microwave and $10 \% \mathrm{Na}_{2} \mathrm{CO}_{3}-60$ min microwave, respectively, accounting to a decrease of 14.3 and $15.5 \%$ in comparison to that of the control $(23.8 \%)$. Decrease in lignin and silica was found to be significant with respect to the increasing $\mathrm{Na}_{2}$ $\mathrm{CO}_{3}$ concentration and non-significant with respect to the increase of microwave duration. Lignin get decreased to a minimum of 4.9 and $4.6 \%$ for 30 and $60 \mathrm{~min}$ microwave, respectively, at $10 \%$ concentration indicating a decrease of 18.3 and $23.3 \%$ as compared to the control with $6 \%$ lignin. Decrease in silica was profound and appreciable with $100 \%$ silica removal at 8 and $10 \%$ concentration.

Solubilization of some of the components might have led to the decrease in TS with the increasing microwave duration. Decrease in ash content was obvious because of the fact that VS gets increased. Decrease in total sugars could be the result of conversion of hemi-cellulose to other degradation products as the hemi-cellulose content was also found to decrease with the increasing $\mathrm{Na}_{2} \mathrm{CO}_{3}$ concentration and microwave duration. Increase in cellulose was the clear-cut case of the decrease in lignin content which could be the result of solubilization of the lignin by the action of $\mathrm{Na}_{2} \mathrm{CO}_{3}$ in combination with microwave irradiation. Decrease in silica was the result of removal of silica by $\mathrm{Na}_{2} \mathrm{CO}_{3}$ which has also been confirmed by Jan and Alexandra (2006).

Change in surface properties of the pretreated PS

The change in surface properties of the $4 \% \mathrm{Na}_{2} \mathrm{CO}_{3}$ - and $10 \% \mathrm{Na}_{2} \mathrm{CO}_{3}-60$ min microwave-pretreated PS with respect to that of the control is shown in Fig. 1. In Fig. 1a, the untreated PS was found to possess an intact epidermis covered with phytoliths which are actually silica-storing nodules, while in Fig. 1b, the surface of PS was seen partially broken and in Fig. 1c, the surface of the PS was seen completely broken with tearing of different layers of PS, thereby leading to the ultimate removal of silica and the recalcitrant lignin as well. These changes in the pretreated paddy are supposed to enhance the PS digestibility.

Effect of $\mathrm{Na}_{2} \mathrm{CO}_{3}$ pretreatment on biogas production

4 and $10 \% \mathrm{Na}_{2} \mathrm{CO}_{3}$ concentration were selected on the basis of significant and maximum enhancement in the digestibility of PS, respectively. Results from Table 3 indicate that the increase in biogas production in $\mathrm{Na}_{2} \mathrm{CO}_{3}$-soaked PS ranged from 2621 biogas/kg PS ( $10 \% \mathrm{Na}_{2} \mathrm{CO}_{3}-48 \mathrm{~h}$ soaking) to 3071 biogas $/ \mathrm{kg}$ PS ( $4 \% \mathrm{Na}_{2} \mathrm{CO}_{3}-48 \mathrm{~h}$ soaking) indicating an increase of 20.7 and $41.5 \%$ than that of the control (217 1 biogas/kg PS). TS and VS of the mixture were found to increase both with the increasing $\mathrm{Na}_{2} \mathrm{CO}_{3}$ concentration and soaking period reaching a maximum of 22.5 and $82.5 \%$ (10 \% $\mathrm{Na}_{2} \mathrm{CO}_{3}-48 \mathrm{~h}$ soaking), respectively, from $20.3 \% \mathrm{TS}$ and $71.9 \%$ VS in control.

In case of microwave supplementation, the enhancement in biogas production from pretreated PS ranged between 274 1/kg PS (10\% $\mathrm{Na}_{2} \mathrm{CO}_{3}-60 \mathrm{~min}$ microwave) and 335 $1 / \mathrm{kg}$ PS (4\% $\mathrm{Na}_{2} \mathrm{CO}_{3}-60 \mathrm{~min}$ microwave) corresponding to an increase of 26.3 and $54.4 \%$ than that of the control (217 l biogas $/ \mathrm{kg}$ PS). TS reached a maximum of $23.2 \%$ while VS increased to $83.2 \%$ in $10 \% \mathrm{Na}_{2} \mathrm{CO}_{3}-60 \mathrm{~min}$ microwave pretreatment.

Despite the maximum digestibility of $10 \% \mathrm{Na}_{2} \mathrm{CO}_{3}$ 60 min microwave-pretreated PS, the biogas produced was minimum which could be associated with the negative effects of the higher concentration of the chemical used. So $4 \% \mathrm{Na}_{2} \mathrm{CO}_{3}-60$ min microwave pretreatment was found to be the best in terms of biogas production. 


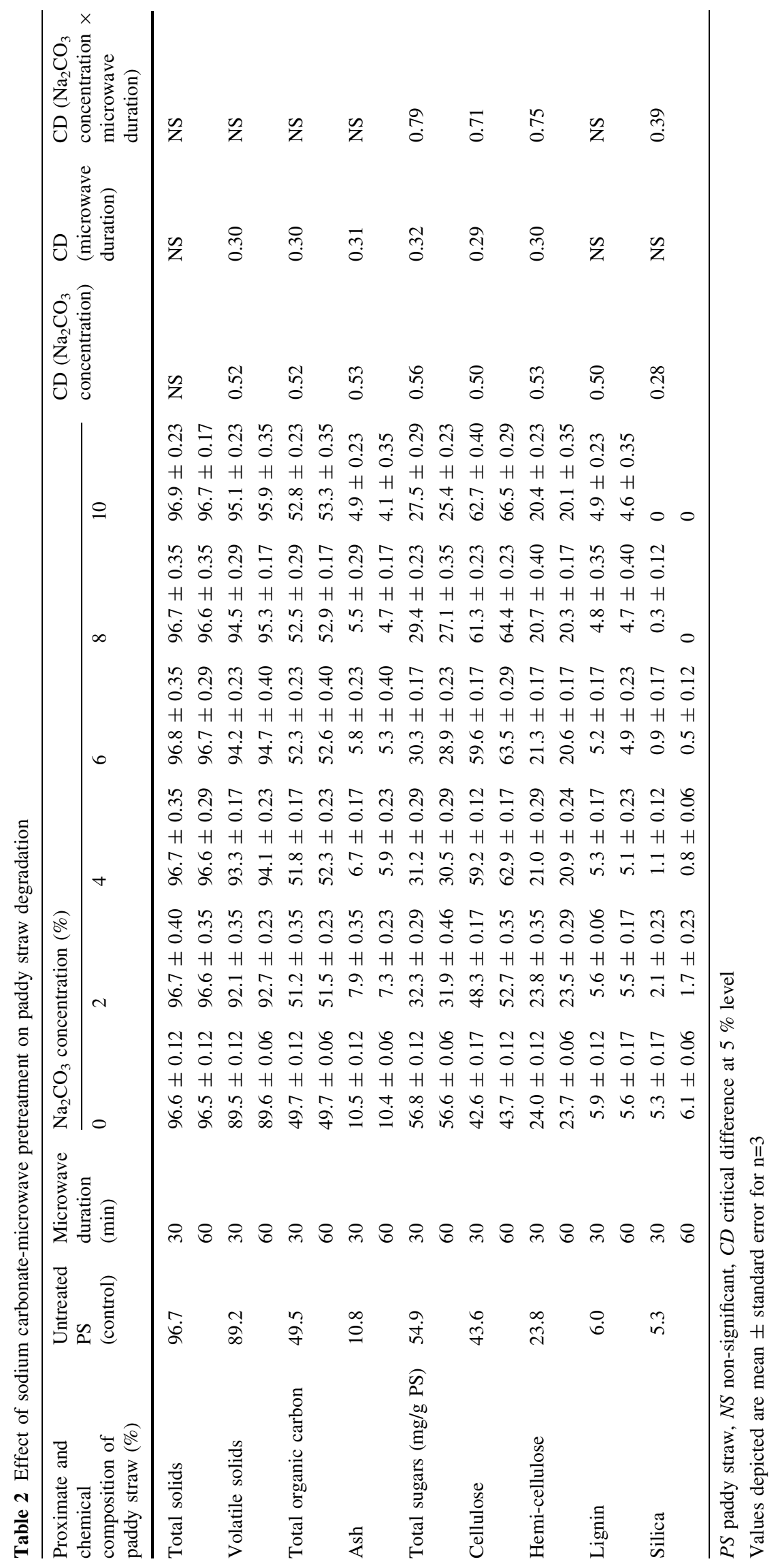


Fig. 1 Scanning electron micrograph(s) of the pretreated paddy straw
Fig.

Fig. 1 Scanning Electron Micrograph

Description

(a)

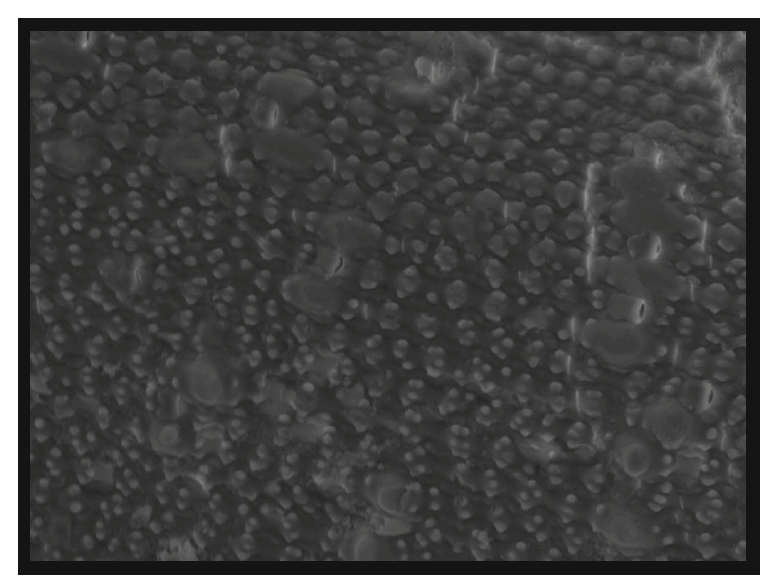

Control/Untreated

paddy straw (b)

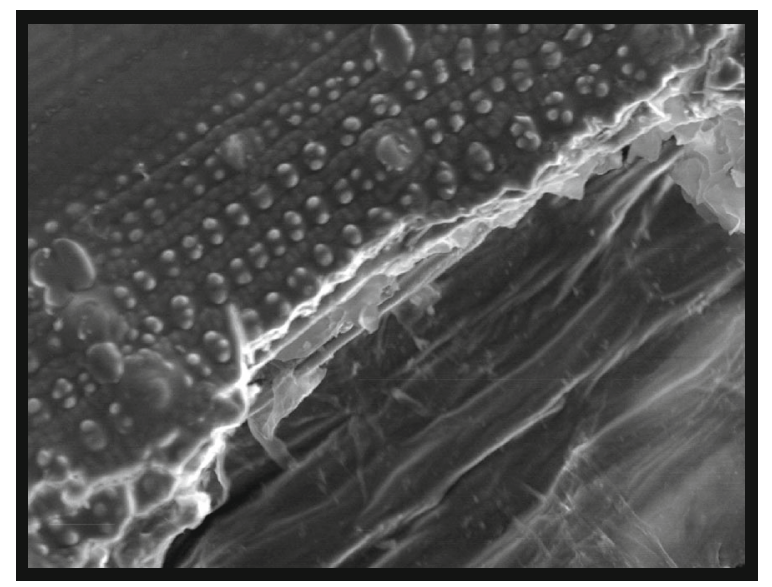

(c)

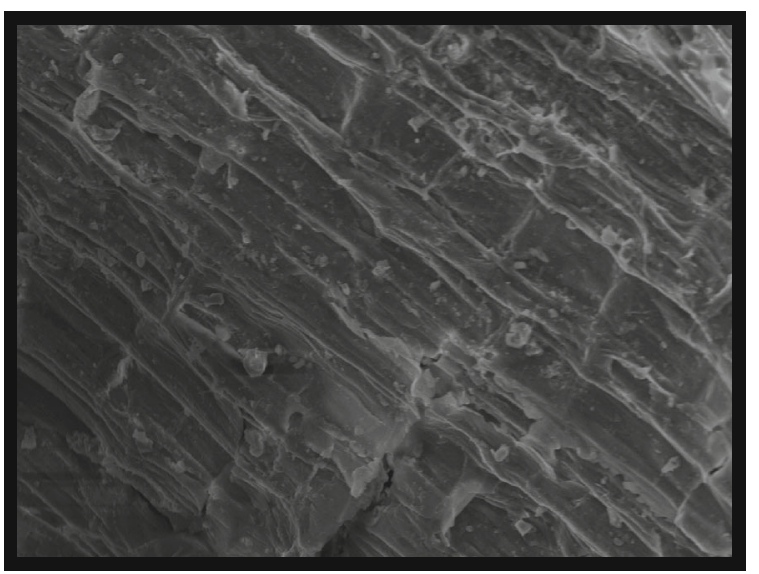

$4 \% \mathrm{Na}_{2} \mathrm{CO}_{3}-60 \mathrm{~min}$

microwave pretreated

paddy straw
$10 \% \mathrm{Na}_{2} \mathrm{CO}_{3}-60 \mathrm{~min}$ microwave pretreated paddy straw

\section{Conclusion}

$4 \% \mathrm{Na}_{2} \mathrm{CO}_{3}-60$ min microwave pretreatment was found to be the best pretreatment with significant enhancement in PS digestibility and $54.4 \%$ increase in biogas production.
Although the maximum digestibility of PS was seen in case of $10 \% \mathrm{Na}_{2} \mathrm{CO}_{3}-60 \mathrm{~min}$ microwave pretreatment, the increase in biogas production was not much appreciable which could be the result of inhibitory/toxic effects of higher concentration. Amongst the different parameters of 
Table 3 Effect of sodium carbonate (soaking and microwave) pretreatment on biogas production

\begin{tabular}{|c|c|c|c|c|}
\hline \multirow[t]{2}{*}{ Parameters } & \multirow[t]{2}{*}{ Pretreatment } & \multirow[t]{2}{*}{ Control } & \multicolumn{2}{|c|}{$\mathrm{Na}_{2} \mathrm{CO}_{3}$ concentration $(\%)$} \\
\hline & & & 4 & 10 \\
\hline \multirow[t]{4}{*}{ Total solids $(\%)$ of the mixture } & $24 \mathrm{~h}$ soaking & \multirow[t]{4}{*}{20.3} & $20.5 \pm 0.75$ & $21.9 \pm 0.98$ \\
\hline & $48 \mathrm{~h}$ soaking & & $21.2 \pm 0.69$ & $22.5 \pm 0.87$ \\
\hline & 30 min microwave & & $20.9 \pm 0.81$ & $22.5 \pm 0.58$ \\
\hline & 60 min microwave & & $21.8 \pm 0.46$ & $23.2 \pm 0.58$ \\
\hline \multirow[t]{4}{*}{ Volatile solids (\%) of the mixture } & $24 \mathrm{~h}$ soaking & \multirow[t]{4}{*}{71.9} & $75.7 \pm 0.40$ & $80.3 \pm 0.29$ \\
\hline & $48 \mathrm{~h}$ soaking & & $77.9 \pm 0.52$ & $82.5 \pm 0.52$ \\
\hline & 30 min microwave & & $76.2 \pm 0.58$ & $81.1 \pm 0.64$ \\
\hline & 60 min microwave & & $80.6 \pm 0.35$ & $83.2 \pm 0.40$ \\
\hline \multirow[t]{4}{*}{ Biogas (1/kg PS) } & $24 \mathrm{~h}$ soaking & \multirow[t]{4}{*}{217.0} & $289.0 \pm 22.5$ & $278.0 \pm 13.3$ \\
\hline & $48 \mathrm{~h}$ soaking & & $307.0 \pm 24.8$ & $262.0 \pm 18.5$ \\
\hline & 30 min microwave & & $302.0 \pm 24.2$ & $297.0 \pm 27.1$ \\
\hline & 60 min microwave & & $335.0 \pm 20.2$ & $274.0 \pm 13.8$ \\
\hline \multirow[t]{4}{*}{ Percent increase in biogas production from control } & $24 \mathrm{~h}$ soaking & \multirow[t]{4}{*}{0.0} & 33.2 & 28.1 \\
\hline & $48 \mathrm{~h}$ soaking & & 41.5 & 20.7 \\
\hline & 30 min microwave & & 39.2 & 36.9 \\
\hline & $60 \mathrm{~min}$ microwave & & 54.4 & 26.3 \\
\hline
\end{tabular}

Control untreated paddy straw, $P S$ paddy straw, Values depicted are mean \pm standard error for $\mathrm{n}=3$

proximate and chemical composition of PS, silica was found to be the most reliable factor in determining PS digestibility. The lesser the silica content, the higher the PS digestibility and biogas production. In nutshell, silica removal is the most crucial step in enhancement of PS digestibility and biogas production.

Open Access This article is distributed under the terms of the Creative Commons Attribution License which permits any use, distribution, and reproduction in any medium, provided the original author(s) and the source are credited.

\section{References}

Azuma J, Tanaka F, Koshijima T (1984) Enhancement of enzymatic susceptibility of lignocellulosic wastes by microwave irradiation. J Ferment Technol 62(4):377-384

Dubois M, Gilles KA, Hamilton JK, Rebers PA, Smith F (1956) Calorimetric method for determination of sugars and related substances. Anal Chem 28:350-356

Frank JR, Smith WH (1988) Introduction to methane from biomass: a systems approach. In: Smith WH, Frank JR (eds) Methane from biomass: a systems approach. Elsevier Applied Science, London

Gunaseelan VN (1997) Anaerobic digestion of biomass for methane production: a review. Biomass Bioenergy 13(1-2):83-114

Hendriks ATWM, Zeeman G (2009) Pretreatments to enhance the digestibility of lignocellulosic biomass. Bioresour Technol 100:10-18

Holtzapple MT, Davison RR (1999) Methods of biomass pretreatments. U.S. Patent 5865898

Jan P, Alexandra P (2006) Process of removing silica from cellulosic material. US Patent 20060225852

Kashyap DR, Dadhich KS, Sharma SK (2003) Biomethanation under psychrophilic conditions: a review. Bioresour Technol 87:147-153
Khan AW, Miller SS, Murray WD (1983) Development of a two phase combination fermentor for conversion of cellulose to methane. Biotechnol Bioeng 25:1571-1579

Kitchaiya P, Intanakul P, Krairish M (2003) Enhancement of enzymatic hydrolysis of lignocellulosic wastes by microwave pretreatment under atmospheric pressure. J Wood Chem Technol 23(2):217-225

Ma H, Liu WW, Chen X, Wu YJ, Yu ZL (2009) Enhanced enzymatic saccharification of rice straw by microwave pretreatment. Bioresour Technol 100:1279-1284

Moseir N, Wyman C, Dale B, Elander R, Lee YY, Holtzapple M, Ladisch $M$ (2005) Features of promising technologies for pretreatment of lignocellulosic biomass. Bioresour Technol 96(6):673-686

Okano K, Kitagawa M, Sasaki Y, Watanabe T (2005) Conversion of Japanese red cedar (Cryptomeria japonica) into a feed for ruminants by white-rot basidiomycetes. Anim Feed Sci Technol 120:235-243

Ooshima H, Aso K, Harano Y (1984) Microwave treatment of cellulosic materials for their enzymatic hydrolysis. Biotechnol Lett 6(5):289-294

Park SY, Koda K, Matsumoto Y, Meshitsuka G, Iiyama K (2000) Oxygen weak base pulping of rice straw with minimum silica removal. Jpn TAPPI J 54(9):1245-1251

Pauss A, Naveau H, Nyns EJ (1987) Biogas production. In: Hall DO, Overend RP (eds) Biomass: regenerable energy. Wiley-Interscience Publications, New York, pp 273-291

Ragauskas AJ, Williams CK, Davison BH, Britovsek G, Cairney J, Eckert CA, Frederick WJJR, Hallet JP, Leak DJ, Liotta CL (2006) The path forward for biofuels and biomaterials. Science 311:484-489

Saratale GD, Chen SD, Lo YC, Saratale RG, Chang JS (2008) Outlook of biohydrogen production from lignocellulosic feedstock using dark fermentation-a review. J Sci Ind Res 67:962-979

Sun Y, Cheng J (2002) Hydrolysis of lignocellulosic materials for ethanol production: a review. Bioresour Technol 83:1-11 
Thiex NJW (2000) Animal feed. In: Official methods of analysis, 17th edn. Association of Official Analytical Chemists (AOAC), Gaithersburg

Van Soest PJ (2006) Rice straw, the role silica and treatments to improve quality. Anim Feed Sci Technol 130:137-171

Wang JK, Liu JX, Li JY, Wu YM, Ye JA (2007) Histological and rumen degradation changes of rice straw stem epidermis as influenced by chemical pretreatment. Anim Feed Sci Technol 136(1-2):51-62

Xiong J, Ye J, Liang WZ, Fan PM (2000) Influence of microwave on the ultrastructure of cellulose1. J South China Univ Technol 28(3):84-89
Yang DY, Li XJ, Gao ZJ, Wang YW (2003) Improving biogas production of corn stalk through chemical and biological pretreatment: a preliminary comparison study. Trans Chin Soc Agric Eng 19(5):209-213

Zhang YHP, Lynd LR (2004) Toward an aggregated understanding of enzymatic hydrolysis of cellulose: non complexed cellulase systems. Biotechnol Bioeng 88(7):797-824

Zhu S, Wu Y, Yu Z, Liao J, Zhang Y (2005) Pretreatment by microwave/alkali of rice straw and its enzymic hydrolysis. Process Biochem 40:3082-3086 